\title{
Efficacy of dry needling in TMD treatment: clinical case report
}

\author{
A eficácia do agullhamento à seco no tratamento da DTM: relato de caso clínico \\ La eficiencia de la aguja seca en el tratamiento del DTM: reporte de caso clínico
}

Received: 02/19/2021 | Reviewed: 02/27/2021 | Accept: 03/03/2021 | Published: 03/11/2021

\author{
Andressa Silva de Oliveira \\ ORCID: https://orcid.org/ 0000-0001-9015-844X \\ Faculdade Paulo Picanço, Brasil \\ E-mail: andressa_oliveira21@ outlook.com \\ Italo Hudson Tavares Maia \\ ORCID: https://orcid.org/ 0000-0003-4274-115X \\ Faculdade Paulo Picanço, Brasil \\ E-mail: italohudson98@ hotmail.com \\ Tainah Oliveira Rifane \\ ORCID: https://orcid.org/ 0000-0001-6120-1672 \\ Faculdade Paulo Picanço, Brasil \\ E-mail: tainah08@gmail.com \\ Francisbênia Alves Silvestre \\ ORCID: https://orcid.org/ 0000-0001-8620-8678 \\ Faculdade Paulo Picanço, Brasil \\ E-mail: beniaasilvestre@gmail.com \\ Bárbara de Fátima Barboza de Freitas \\ ORCID: https://orcid.org/ 0000-0002-7127-8056 \\ Faculdade Paulo Picanço, Brasil \\ E-mail: barbarafreitas130599@gmail.com \\ Paulo Roberto Barroso Picanço \\ ORCID: https://orcid.org/0000-0002-7326-3667 \\ Faculdade Paulo Picanço, Brasil \\ E-mail: paulo.picanco@facpp.edu.br \\ Victor Pinheiro Feitosa \\ ORCID: https://orcid.org/0000-0001-8795-9967 \\ Faculdade Paulo Picanço, Brasil \\ E-mail: victor.feitosa@facpp.edu.br \\ Aline Kércia Adeodato Leitão \\ ORCID: https://orcid.org/0000-0001-6338-9939 \\ Faculdade Paulo Picanço, Brasil \\ E-mail: aline.kercia@facpp.edu.br
}

\begin{abstract}
The purpose of this article is to report a clinical case of a patient with TMD, evaluating the efficacy of dry needling as a treatment. The study was carried out in a dental clinic of higher education, where the evaluation of the patient was performed in order to conclude a correct diagnosis complementing with the use of dry needling. Patient, female, 38 years old, reported pain throughout the muscular region of the face, where it was more pronounced in the parotidmassometric region, with spreading to the temporal region. After performing the evaluation in addition to the percussion and palpation tests, the patient was diagnosed with spreading myofascial pain, in addition to headache attributed to TMD bilaterally. As a therapeutic approach, the dry needling technique was performed, in addition to the orientation of Cognitive Behavioral Therapy, since the patient reported having parafunctional habits. The techniques used produced an effective improvement to the patient, where the patient reports a relief of the muscular pains when performing the dry needling.
\end{abstract}

Keywords: Temporomandibular disorder; Dry needling; Orofacial pain.

\section{Resumo}

O objetivo desse artigo é relatar um caso clínico de uma paciente com disfunção temporomandibular muscular (DTM), avaliando a eficácia do agulhamento à seco como tratamento. O estudo foi realizado em uma clínica odontológica de ensino superior, onde ocorreu a avaliação do paciente com o intuito de concluir um correto diagnóstico complementando com a utilização do agulhamento à seco. Paciente, gênero feminino, 38 anos, relatou dor em toda região muscular da face, onde a mesma era mais acentuada na região parotídea-massetérica, com espalhamento para região temporal. Após a realização da avaliação somado aos testes de percussão e palpação, a paciente foi diagnosticada com dor miofascial com espalhamento, além de cefaleia atribuída a DTM bilateralmente. Como conduta 
terapêutica foi realizado a técnica de agulhamento à seco, além da orientação da Terapia Cognitiva Comportamental, uma vez que o paciente relatou ter hábitos parafuncionais. As técnicas utilizadas produziram uma melhora efetiva ao paciente, onde o mesmo relata sentir um alívio as dores musculares perante a realização do agulhamento à seco.

Palavras-chave: Disfunção temporomandibular; Agulhamento seco; Dor orofacial.

\section{Resumen}

El propósito de este artículo es reportar un caso clínico de un paciente con trastorno temporomandibular muscular (TTM), evaluando la efectividad de la punción seca como tratamiento. El estudio se llevó a cabo en una clínica odontológica de educación superior, donde se evaluó al paciente con el fin de completar un diagnóstico correcto, complementando con el uso de agujas secas. Una paciente de 38 años refirió dolor en toda la región de los músculos faciales, donde era más pronunciado en la región parótida-maseteriana, con extensión a la región temporal. Tras realizar la evaluación además de las pruebas de percusión y palpación, se diagnosticó a la paciente de dolor miofascial diseminado, además de cefalea atribuida a TTM bilateralmente. Como abordaje terapéutico se realizó la técnica de punción seca, además de la orientación de la Terapia Cognitivo Conductual, ya que el paciente refirió tener hábitos parafuncionales. Las técnicas empleadas produjeron una mejoría efectiva para el paciente, donde informa sentir un alivio de los dolores musculares al realizar una punción seca.

Palabras clave: Trastorno temporomandibular; Punción seca; Dolor orofacial.

\section{Introduction}

Temporomandibular disorders (TMDs) are recognized as a group of musculoskeletal and neuromuscular conditions involving the temporomandibular joints (TMJs), masticatory muscles and all associated tissues (Greene et al., 2010).

The etiology of TMD is multifactorial and may be related to stress, emotional tension, occlusal interference, postural changes, parafunctional habits, extrinsic or intrinsic joint changes or the combination of these factors (Le Resche et al., 1997). In addition, unilateral chewing, nutritional deficiency and systemic factors may contribute to the onset of TMD (Alencar, 2005). However, despite the evolution of TMD research, its etiology still has controversies.

The Research Diagnostic Criteria for Temporomandibular Disorders (RDC-TMD) is a validated and reliable method for TMD assessment and diagnosis. It is based on two axes: AXIS I is the physical examination that subdivides TMD into three groups: myofascial pain (group I), disc displacement (group II) and arthralgia, osteoarthritis and osteoarthritis (group III) (Battistella et al., 2016). AXIS II comprises a biopsychosocial assessment designed to screen patients' psychological status and rate them on a chronic pain scale.

Muscle (group I) is the most common TMD subtype origin (Scrivani et al., 2008). Patients with muscular TMD report pain in the face, jaw, temporal region, ear and often report headache (Anderson et al., 2005, Svenson, 2005) There is a strong association between TMD and headache, especially with migraine (Bevilaqua - Grossi et al., 2010, Gonçalves et al., 2011).

Dry needling is one of the procedures designed to remedy myofascial pain. The technique consists on the insertion of monofilament needles that, when penetrated into the muscles, stimulate the points underlying the trigger point region in order to regulate neuromuscular pain and undo the nodule, resulting in a local contraction response of muscle fibers.

However, despite being a viable option the knowledge regards to the performance of this technique and its prognosis in the treatment of TMD with dry needling is unsatisfactory, emphasizing the importance of a detailed report on the effectiveness of this technique.

The aim of this paper is to describe a case report in order to provide available data on the effect of dry needling treatment on myofascial pain associated with TMD.

\section{Methodology}

\subsection{Case report}

A 38-year-old white female patient sought a higher education institution complaining of pain in the parotidmasseteric region, where it extended to the cervical portion, associated with headache in the temporal region. The pain was 
intensifying for at least ten years. The patient reported having undergone treatment with occlusal splint some years ago, although without satisfactory results.

The frequency of pain was constant, of pulsatile quality and of great intensity. The patient reported chewing as a factor to aggravate symptoms, occurring more often during meals. At physical examination, the maximum opening of the mouth observed was $38 \mathrm{~mm}$, with pain, without joint noises. Muscle palpation reported pain throughout the left temporalis muscle, severe pain throughout the masseter muscle region bilaterally, and tenderness in the cervical muscles. According to the Visual Analysis Scale (VAS), at the time of the anamnesis, the patient indicated her pain on the number 8 scale (0: no pain; 10: worst pain). The diagnosis made after anamnesis and physical examination was myofascial pain with spread on the left side, with reference on the right side, both located in the masseter muscle, and bilateral headache attributed to TMD.

\subsubsection{Treatment Alternative}

Based on the diagnosis of spreading myofascial pain, it was suggested to the patient:

- Dry needling sessions to undo the trigger points in the masseter and temporalis muscle. Thereafter, thermotherapy would be performed on the muscles to provide pain relief.

- Use of occlusal splint.

\subsubsection{Treatment Performed}

The patient chose to perform the dry needling sessions, since through the explanation of the procedure, she reported not being afraid of needles.

\section{Results}

\subsection{Treatment Evolution}

The first session of dry needling was performed on the first day of patient treatment. The area of skin receiving the needle was disinfected with $70 \%$ alcohol-soaked gauze as preparation for the needling. Subsequently, the trigger point in the right masseter muscle was located, and soon after the acupuncture needle was inserted. The following step was to stimulate the trigger point in all directions, alternating with the needle at rest. Each session lasted 20 minutes. At the end of the procedure, the patient already reported muscle relief. (Figures 1 e 2) 
Research, Society and Development, v. 10, n. 3, e16810313131, 2021

(CC BY 4.0) | ISSN 2525-3409 | DOI: http://dx.doi.org/10.33448/rsd-v10i3.13131

Figure 1. First session of dry needling.

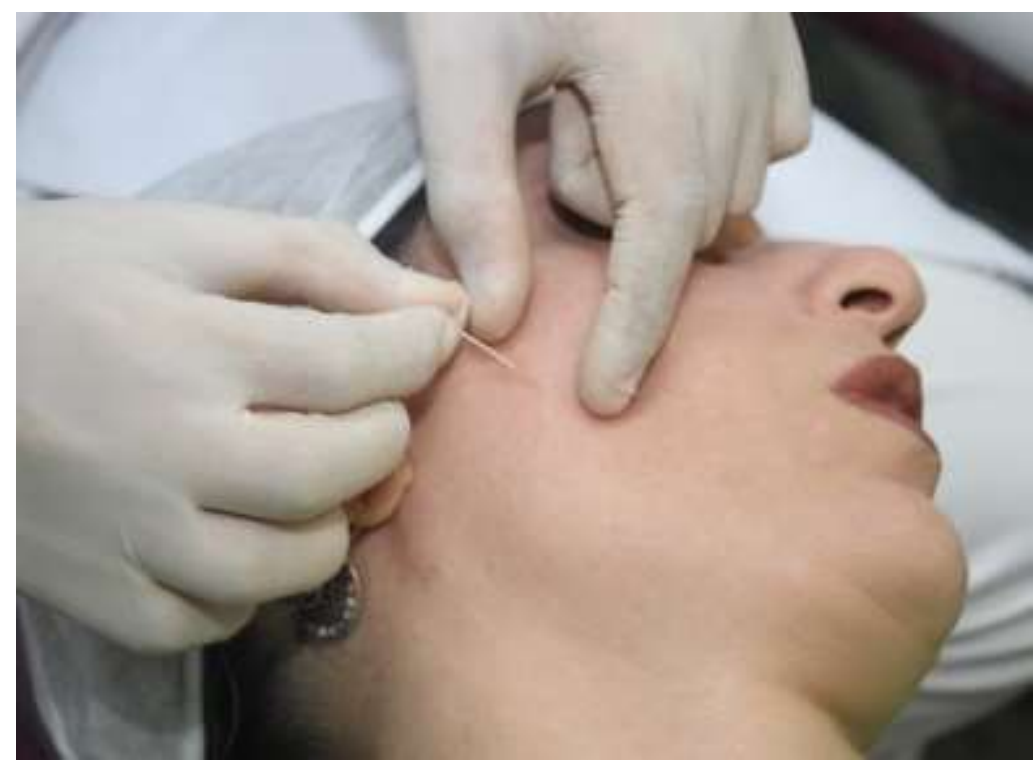

Source: Authors.

Figure 2. In the first session, the maximum opening of the mouth observed was $38 \mathrm{~mm}$.

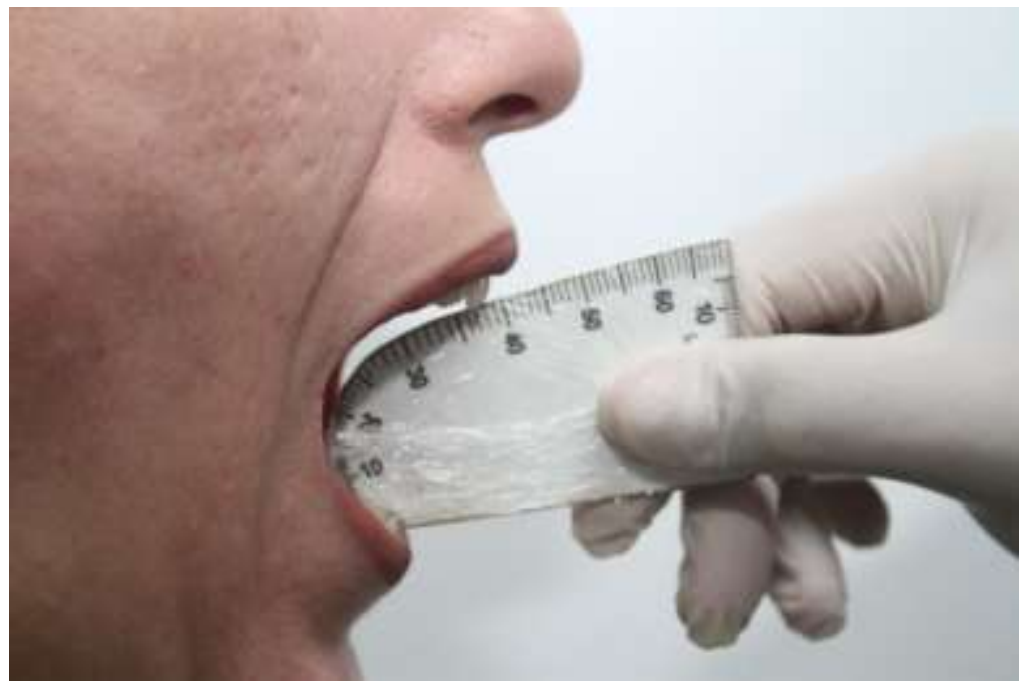

Source: Authors.

In the second session, the patient's pain was reassessed. In the assessment of pain intensity through VAS, the patient declared score 5, demonstrating pain reduction. The maximum opening of the mouth presented greater amplitude, $43 \mathrm{~mm}$, without pain and without noise. The procedures aforementioned in the first session were repeated. (Figure 3) 
Figure 3. In the second and third session, the maximum opening of the mouth presented greater amplitude, $43 \mathrm{~mm}$.

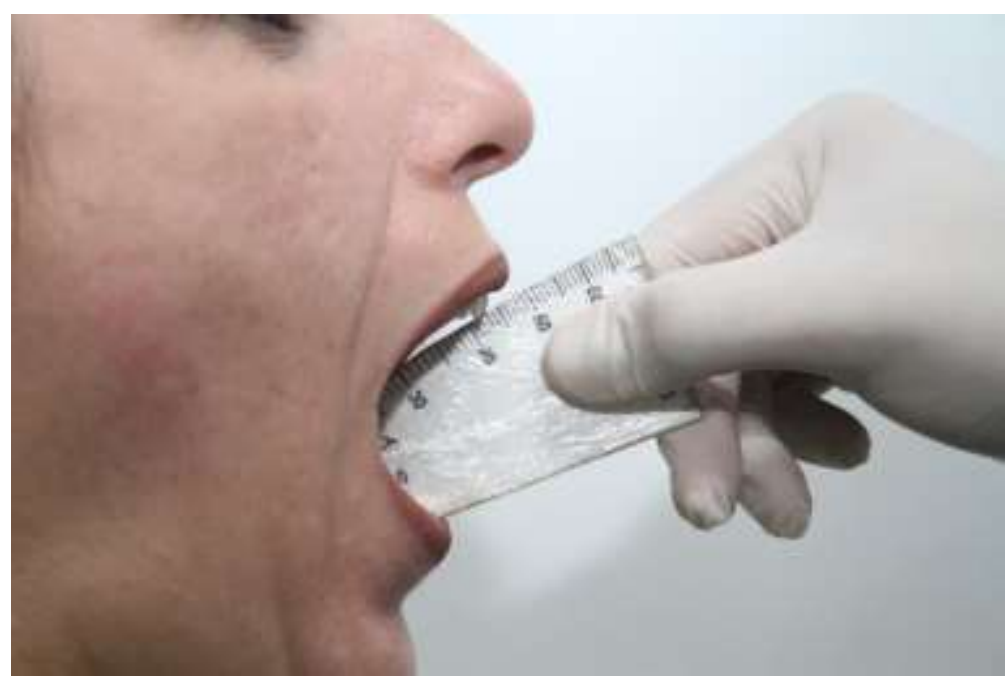

Source: Authors.

The sessions were spaced each month. In the third session, the patient returned and was reevaluated. The patient declared grade 3 in the assessment of pain intensity through VAS. The maximum mouth opening remained at 43 mm, without pain and without noise. In that same day another needling session was performed.

One month after the third session, the patient returned and the pain intensity was verified by VAS, which remained at 0 at the time of reevaluation and weeks after the procedure. Thus, it could be concluded that there was a $100 \%$ reduction in pain compared to pain present before the beginning of treatment. The maximum mouth opening without pain and noise increased to $48 \mathrm{~mm}$, representing an increase of $10 \mathrm{~mm}$ compared to the initial measurement. (Figure 4)

Figure 4. In the four and last session, the maximum opening of the mouth observed was $48 \mathrm{~mm}$, without pain and joint noises.

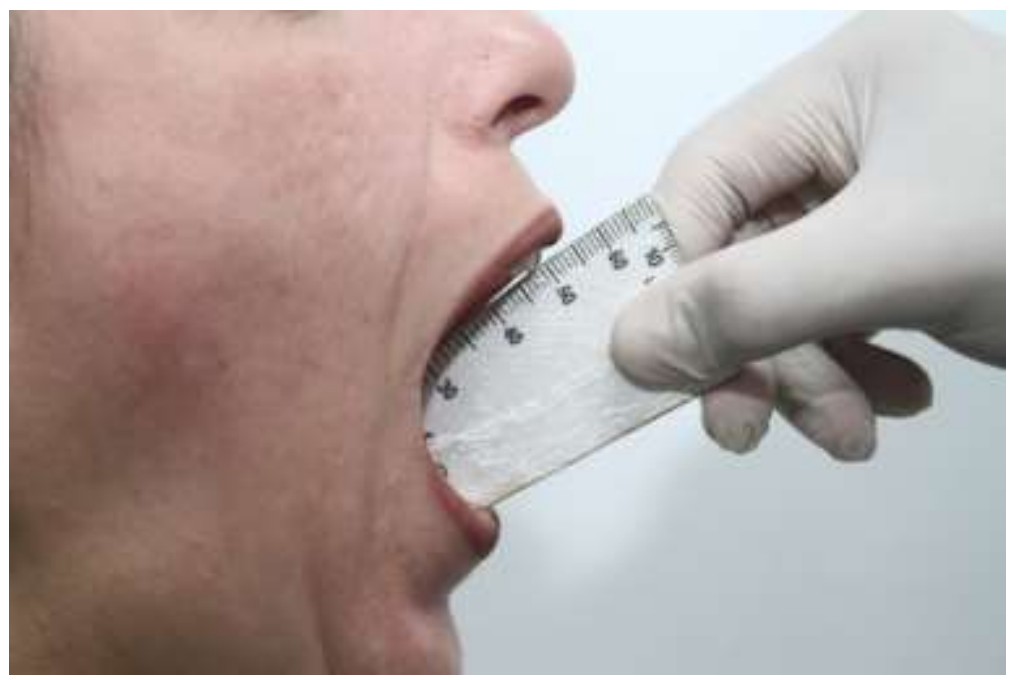

Source: Authors.

\section{Discussion}

Mostly, the development of temporomandibular dysfunction encompasses muscle pain as one of its main symptoms. In the case described, constant pain was observed throughout the masticatory muscles, resulting in a referred myofascial pain, 
accompanied by headache attributed to TMD. After the case analysis and correct diagnosis, the treatment plan was made, choosing dry needling sessions. After the treatment evolution, a significant improvement of the case was observed, through the analysis of the maximum buccal opening, in which the patient presented an increase of $10 \mathrm{~mm}$ when compared to the initial session. It was also observed the reduction of the evaluation grade by the Visual Analogue Scale (VAS).

The diagnosis of myofascial pain is defined as pain at the muscle palpation site, where this pain is referred beyond its place of origin, replicating the patient's main complaint of pain. It may be aggravated by mandibular, functional or parafunctional movements (Tesch et al., 2019). The referred pain comes from tense, palpable and hypersensitive muscle bands called myofascial trigger points (MTPs).

In addition, myofascial pain resulted in a headache attributed to TMD. Epidemiological studies in adults suggest an association between headache and TMD and both have similar signs and symptoms (Ciancaglini et al., 2001, Lupdi et al., 2007). The severity of TMD seems to be correlated with the intensity and frequency with which headache occurs. Thus, TMD treatment may provide a positive result in the reduction of headache (Schiffman et al., 1995, Liljeström et al., 2001).

A population study of TMD and headache concluded that individuals with TMD symptoms are 1.8 to 2 times more likely to have headache (Ciancaglini R et al., 2001). According to the literature, pericranial muscle pain is a common clinical finding in patients with TMD, tension-type headache (TTH) and migraine (Haley et al., 1993, Graff - Radford et al., 2007, Bendtsen L et al., 2000). Prolonged nociceptive impulses from the muscles of the head region are suggested to increase pain sensitivity and decrease the local pain threshold. These impulses would lead to central sensitization in affected patients, subsequently contributing to the chronicity of pain and headache (Buchgreitz et al., 2006).

The data from the current literature support the idea of a close interrelation between primary headache, TMD and pericranial sensitivity. Authors suggest the existence of a common pathophysiological mechanism involved with the caudate trigeminal nucleus. This nerve, responsible for orofacial sensitivity, would intertwine the signs and symptoms of these conditions. It is also suggested that one problem would affect the other, acting as a predisposing, triggering or aggravating factor (Graff - Radford, 2007, Buchgreitz et al., 2008).

According to Machado et al, 2018, dry needling (DN) is a treatment modality that involves inserting a needle into trigger points to deactivate them. Stimulation of the needle at these points produces an analgesic effect as a result of affecting somatosensory thresholds. Satisfactory results are achieved in local and referred pain relief. Moreover, Tesch et al, 2019 prove that the effectiveness of dry needling lies in the mechanical disruption of the dysfunctional motor integrity of the endplates. Dry needling may also activate the descent of the pain inhibitory system and cause local deactivation of MTPs.

In addition to dry needling, another treatment alternative has been suggested, such as therapy with the use of occlusal splint, which is a type of myorelaxant splint widely used in the treatment of temporomandibular disorders due to its low cost and its high rate of treatment success.

The stabilizing occlusal splint, also known as conventional myorelaxant or Michigan splint, is the most used due to its less risk of irreversible occlusal changes to the patient, such as anterior opening bite (Portero et al 2009). According to Ramjord and Ash (1984), the use of a well-designed occlusal splint is the efficient therapy for most structural disorders of the chewing system. There are still controversy regards to which splint should be used to reduce pain in masticatory muscles: rigid or resilient. Pettengill et al. (1998) state that both are equally useful in treating masticatory pain as short-term therapy. Alencar and Becker (2009) compared the effectiveness of different occlusal splints associated with self-care in the management of orofacial pain signs. As a conclusion, all patients studied improved over time and all occlusal splints offered benefit. 
Despite the positive effect of occlusion splint on TMD signs and symptoms, Felício et al. (2003) state that some patients do not respond to splint treatment, and it may not produce full resolution of the problem for all individuals, suggesting the need for other therapeutic procedures.

Furthermore, a factor that helps in the effectiveness of occlusal splints is the behavioral condition of the patient using it. A recommendation in the treatment of TMDs is the control of habits, decreasing muscle or joint disorder. Habits such as tooth clenching, bruxism or stressful situations may interfere the splints effectiveness. Therefore, awareness regards to the correct use of the splints is as important as the perception of incorrect postural habits.

However, the patient decided not to opt for the use of occlusal splint, as she had already undergone this treatment before and found no improvement in her temporomandibular disorder.

Females present temporomandibular disorders more frequently and more severely than males. Correia and Ramos et al. (1991) found a predominance of females with signs and symptoms of this dysfunction. Similarly, Carlsson G et al. (1995) found correlations between TMD and hormonal influence due its frequent manifestation in females. Le Resche et al. (2003) found clinical variations in pain intensity in women with TMD during the menstrual cycle. The authors mention that the highest pain values coincided with the period of higher estrogen concentrations.

In addition to gender-related effects, Biasotto-Gonzalez et al. (2005) exposes that TMD has its highest prevalence at certain ages, especially in patients between 20 and 45 years. Whereas until the age of 40 , the main cause is muscle origin, myogenic TMD, and from 40 years the main etiological factor is joint degeneration, arthogenic TMD.

Alamoudi et al. (1998) showed that functional disorders of the masticatory system are common in children and adolescents, tending to increase in adulthood. Thilander et al. (2002) state that TMDs may present parafunctional habits and occlusal changes during childhood as main etiological factors. Yap et al. (2002) emphasize that psychological aspects influence TMJ. Tension leads to bruxism, which includes grinding and or clenching teeth. Winocur et al. (2003) state that psychological changes such as anxiety may be a cause of TMD.

Despite the substantial common presence of temporomandibular dysfunction in young adults and patients between the ages of 20 and 45, an overload of the TMJ may occur due to lack of replacement of missing teeth, parafunctional habits, poor occlusion or trauma.

The aforementioned changes may result in temporomandibular dysfunction (TMD) in the elderly public (Almeida et al., 2008). Initially the patient is advised to perform a diet change and control pain through exercise and hot compress application. Pharmacological therapy includes anti-inflammatory agents, analgesics, muscle relaxants and tricyclic antidepressant in certain situations. Notwithstanding the prescription of these medications, $75 \%$ of patients have persistent pain. Other approaches such as acupuncture, cognitive behavioral therapy and botulinum toxin injection may also be put into practice as adjunctive therapy (Mor et al., 2015).

\section{Conclusion}

Indeed, for the desirable improvement of the patient's clinical condition according to the decrease of pain intensity during the needling sessions and the increase of her maximum mouth opening it is possible to conclude that dry needling is an effective method in the treatment of temporomandibular disorder. However, more laboratory and clinical studies are needed in order to enrich more information that addresses the technique of dry needling correlating with TMD.

\section{References}

Alamoudi, N., Farsi, N., Salako, N. O., \& Feteih, R. (1998). Temporomandibular disorders among schoolchildren. The Journal of clinical pediatric dentistry, 22(4), 323-328. 
Alencar, J. F. G. (2005). Occlusion, orofacial pain and headache. Santos

Alencar, F., Jr, \& Becker, A. (2009). Evaluation of different occlusal splints and counselling in the management of myofascial pain dysfunction. Journal of oral rehabilitation, 36(2), 79-85. https://doi.org/10.1111/j.1365-2842.2008.01913.x

Almeida, L. H. M., Farias, A. B. L., Soares, M. S. M., Cruz, J. S. A., Cruz, R. E. S., Lima, M. G. (2008). Temporomandibular disorder in the elderly. Journal of the Faculty of Dentistry -UPF, 13 (1): 35-8

Anderson, G. C., John, M. T., Ohrbach, R., Nixdorf, D. R., Schiffman, E. L., Truelove, E. S., \& List, T. (2011). Influence of headache frequency on clinical signs and symptoms of TMD in subjects with temple headache and TMD pain. Pain, 152(4), 765-771. https://doi.org/10.1016/j.pain.2010.11.007

Battistella, C. B., Guimarães, T, B., Quaglio, C. L. et al. (2016). Axis II biopsychosocial factors of the Diagnostic Criteria for Researching Temporomandibular Disorders in individuals with muscle and migraine temporomandibular disorders. Rev. Pain, 17(1), 19-23

Bendtsen L. Central sensitization in tension-type headache--possible pathophysiological mechanisms. Cephalalgia. 2000 20(5):486-508. 10.1046/j.14682982.2000.00070.x. 11037746 .

Bevilaqua-Grossi, D., Lipton, R. B., Napchan, U., Grosberg, B., Ashina, S., \& Bigal, M. E. (2010). Temporomandibular disorders and cutaneous allodynia are associated in individuals with migraine. Cephalalgia: an international journal of headache, 30(4), 425-432. https://doi.org/10.1111/j.1468-2982.2009.01928.x

Biasotto-Gonzalez, D. A. (2005). Interdisciplinary approach to temporomandibular disorders. Manole

Buchgreitz, L., Lyngberg, A. C., Bendtsen, L., \& Jensen, R. (2006). Frequency of headache is related to sensitization: a population study. Pain, 123(1-2), 1927. https://doi.org/10.1016/j.pain.2006.01.040

Buchgreitz L, Lyngberg A. C, Bendtsen L, Jensen R. Increased pain sensitivity is not a risk factor but a consequence of frequent headache: a population-based follow-up study. 137(3):623-630. 10.1016/j.pain.2007.10.023. Epub 2007 Dec 3. PMID: 18061350.

Carlsson, G., Le Reseche, L., (1995). Epidemiology of temporomandibular disorders. In: Sessle B, Bryant P, Dionne R. Progress in pain research and management. IASP Press 1995; 211-226.

Ciancaglini, R., \& Radaelli, G. (2001). The relationship between headache and symptoms of temporomandibular disorder in the general population. Journal of dentistry, 29(2), 93-98. https://doi.org/10.1016/s0300-5712(00)00042-7

Correia, F. A. S. (1991). Prevalence of symptomatology in temporomandibular joint disorders and its relationship with age, sex and tooth loss. Sao Paulo: University of Sao Paulo

Machado, E., Machado, P., Wandscher, V. F., Marchionatti, A., Zanatta, F. B., \& Kaizer, O. B. (2018). A systematic review of different substance injection and dry needling for treatment of temporomandibular myofascial pain. International journal of oral and maxillofacial surgery, 47(11), 1420-1432. https://doi.org/10.1016/j.ijom.2018.05.003

Felício, C. M., Mazzetto, M. O., Bataglion, C., Silva, M. A. M. R., Hotta, T. H. (2003). Temporomandibular disorder: analysis of the frequency and severity of signs and symptoms before and after the occlusion plaque. J. Bras. Ortodont. Ortop. Facial, 8(43), 48-57

Gonçalves D. A., Camparis, C. M., Speciali, J. G., Franco, A. L., Castanharo, S. M., \& Bigal, M. E. Temporomandibular disorders are differentially associated with headache diagnoses: a controlled study. Clin J Pain. 27(7):611-5. 10.1097/AJP.0b013e31820e12f5.

Graff-Radford S. B. (2007). Temporomandibular disorders and headache. Dental clinics of North America,51(1), 129-vii. https://doi.org/10.1016/j.cden.2006.09.005

Greene, C. S., Klasser, G. D., Epstein, J. B. (2010) Revision of the American Association of Dental Research's Science information statement about temporomandibular disorders. J Can Dent Assoc, 76, a115

Haley, D., Schiffman, E., Baker, C., \& Belgrade, M. (1993). The comparison of patients suffering from temporomandibular disorders and a general headache population. Headache, 33(4), 210-213. https://doi.org/10.1111/j.1526-4610.1993.hed33040210.x

LeResche, L., Saunders, K., Von Korff, M. R., Barlow, W., \& Dworkin, S. F. (1997). Use of exogenous hormones and risk of temporomandibular disorder pain. Pain, 69(1-2), 153-160. https://doi.org/10.1016/s0304-3959(96)03230-7

LeResche, L., Mancl, L., Sherman, J. J., Gandara, B., \& Dworkin, S. F. (2003). Changes in temporomandibular pain and other symptoms across the menstrual cycle. Pain, 106(3), 253-261. https://doi.org/10.1016/j.pain.2003.06.001 .

Liljeström, M. R., Jämsä, A., Le Bell, Y., Alanen, P., Anttila, P., Metsähonkala, L., Aromaa, M., \& Sillanpää, N. (2001). Signs and symptoms of temporomandibular disorders in children with different types of headache. Acta odontologica Scandinavica,59(6), 413-417. https://doi.org/10.1080/000163501317153284.

Lupoli, T. A., \& Lockey, R. F. (2007). Temporomandibular dysfunction: an often overlooked cause of chronic headaches. Annals of allergy, asthma \& immunology: official publication of the American College of Allergy, Asthma, \& Immunology, 99(4), 314-318. https://doi.org/10.1016/S1081-1206(10)60546-

Mor, N., Tang, C., \& Blitzer, A. (2015). Temporomandibular Myofacial Pain Treated with Botulinum Toxin Injection. Toxins, 7(8), 2791-2800. https://doi.org/10.3390/toxins7082791 .

Pettengill, C. A., Growney, M. R., Jr, Schoff, R., \& Kenworthy, C. R. (1998). A pilot study comparing the efficacy of hard and soft stabilizing appliances in treating patients with temporomandibular disorders. The Journal of prosthetic dentistry, 79(2), 165-168. https://doi.org/10.1016/s0022-3913(98)70211-2 
Research, Society and Development, v. 10, n. 3, e16810313131, 2021

(CC BY 4.0) | ISSN 2525-3409 | DOI: http://dx.doi.org/10.33448/rsd-v10i3.13131

Portero, P. P., Kern, R., Kusma, S. Z., \& Grau-Grullón, P. (2009). Occlusal plaques in the treatment of temporomandibular disorders (TMD). Gestão \& Saúde Magazine, Curitiba, 1(1), 36-40

Ramjord, S. I., \&Ash, M. (1984). Occlusion. Inter-American

Ramos, H. A. D. (1992). Signs and symptoms of painful temporomandibular joint disorders. Dental Cad Doc, 34(2), $252-255$.

Schiffman, E., Haley, D., Baker, C., \& Lindgren, B. (1995). Diagnostic criteria for screening headache patients for temporomandibular disorders. Headache, 35(3), 121-124. https://doi.org/10.1111/j.1526-4610.1995.hed3503121.x

Svensson P. (2007). Muscle pain in the head: overlap between temporomandibular disorders and tension-type headaches. Current opinion in neurology, 20(3), 320-325. https://doi.org/10.1097/WCO.0b013e328136c1f9

Tesch, R. S., Macedo, L., Fernandes, F. S., Goffredo Filho, G. S., \& Goes, C. (2019). Effectiveness of dry needling on the local pressure pain threshold in patients with masticatory myofascial pain. Systematic review and preliminary clinical trial. Cranio: the journal of craniomandibular practice, 1-9. Advance online publication. https://doi.org/10.1080/08869634.2019.1588518

Thilander, B., Rubio, G., Pena, L., Mayorga, C. (2002) Prevalence of temporomandibular dysfunction and its association with malocclusion in children and adolescents: an epidemiologic study related to specified stages of dental development. Angle Orthod, 72(2): 146-154.

Winocur, E., Emodi-Perlman, A., Finkelstein, T., Sharabi-Ventura, Y., \& Gavish, A. (2003). Refu'at ha-peh veha-shinayim (1993), 20(1), 62-82.4

Yap, A. U., Tan, K. B., Chua, E. K., \& Tan, H. H. (2002). Depression and somatization in patients with temporomandibular disorders. The Journal of prosthetic dentistry, 88(5), 479-484. https://doi.org/10.1067/mpr.2002.129375 